\title{
Espiritualidade laical na formação de verdadeiros sujeitos eclesiais
}

\section{Lay spirituality in formation of true eclesial subjects}

\author{
Lúcia Pedrosa-Pádua*
}

Recebido: 20/03/2018. Aprovado: 20/04/208.

Resumo: A espiritualidade cristã é integral e integradora. No texto, são articuladas as dimensões pessoal, eclesial, sociopolítica e ecológica da espiritualidade laical. Em cada dimensão, são tratados alguns desafios urgentes na formação dos cristãos leigos e leigas como verdadeiros sujeitos eclesiais, dentre eles: a contemplação do Deus de Jesus Cristo, com sua vida, sua cruz e sua carne; a superação do clericalismo; a construção da comunhão na liberdade e responsabilidade dos sujeitos eclesiais; a superação da divisão entre fé e vida; a não alienação dos problemas ecológicos.

Palavras-chave: Espiritualidade. Laicato. Sujeito eclesial.

Abstract: Christian spirituality is integral and integrating. The text articulates different dimensions of the spirituality of layty: personal, ecclesial, socio-political and ecological dimensions. In each one, are treated some urgent challenges in the formation of layty as true ecclesial subjects, among them: the contemplation of the God of Jesus Christ, with his life, his cross and his flesh; the overcoming of clericalism; the construction of communion in freedom and responsibility of the ecclesial subjects; overcoming of division between faith and life; non-alienation of ecological problems.

Keywords: Spirituality. Laity. Ecclesial subject

* Doutora em Teologia Sistemático-Pastoral (PUC, Rio de Janeiro, 2002). Mestra em Teologia Sistemático-Pastoral (PUC, Rio de Janeiro, 1996). Pesquisadora e professora em tempo contínuo na PUC-Rio. Atua nas áreas de Antropologia Teológica, Mariologia e Espiritualidade. Graduada em Teologia (FAJE, Belo Horizonte, 1992) e em Economia (UFMG, Belo Horizonte, 1985).

E-mail: Ipedrosa@puc-rio.br 


\section{Introdução}

O Ano do Laicato ${ }^{1}$ enseja uma reflexão particular sobre os cristãos leigos e leigas, no momento eclesial e social brasileiro. O laicato é instado a desenvolver uma nova consciência como sujeito na Igreja e fermento bom numa realidade marcada pela corrupção e pela desigualdade.

Neste contexto, o presente artigo contribui com uma reflexão sobre a espiritualidade laical a partir de quatro dimensões: pessoal, eclesial, sociopolítica e ecológica. Em cada dimensão, serão privilegiados aqueles que são, na visão da autora, os principais desafios.

\section{Pano de fundo: O processo de tornar-se sujeito eclesial}

O Documento 105 da CNBB, Cristãos leigos e leigas na Igreja e na Sociedade. Sal da Terra e Luz do Mundo (Mt 5,13-14), baliza a reflexão atual sobre o laicato no Brasil. ${ }^{2}$ Em sua ideia central, afirma que o cristão leigo é convidado a ser verdadeiro sujeito eclesial na Igreja e no mundo. E coloca algumas características deste ser sujeito:

O cristão leigo é verdadeiro sujeito na medida em que cresce na consciência de sua dignidade de batizado, assume de maneira pessoal e livre as interpelações da sua fé, abre-se de maneira integrada às relações fundamentais (com Deus, com o mundo, consigo mesmo e com os outros) e contribui efetivamente na humanização do mundo, rumo a um futuro em que Deus seja tudo em todos. ${ }^{3}$

Ser sujeito, no entanto, depende de um processo que, infelizmente, pode ser malogrado. Assim sendo, a verdadeira chamada da atualidade eclesial, aos cristão leigos e leigas, é entrar na dinâmica de fazer-se sujeito, de passar de fiel passivo a sujeito ativo. ${ }^{4}$ Apesar de o Concílio

1 A CNBB inaugurou o Ano do Laicato na solenidade de Cristo Rei de 2017, com encerramento no mesmo dia, em 2018. A cada ano, nesta Solenidade, será celebrado o Dia Nacional dos Cristãos Leigos e Leigas.

2 CNBB. Cristãos leigos e leigas na Igreja e na Sociedade. Sal da Terra e Luz do Mundo (Mt 5,13-14). Documento 105. Brasília: CNBB, 2016. A partir de agora citado como "CNBB. Documento 105", seguido do número correspondente.

3 CNBB. Documento 105, n. 124.

4 Cf. PASSOS, João Décio. A emergência do sujeito na Igreja. In: Sujeitos no mundo e na Igreja. São Paulo: Paulus, 2014. p. 25-43. 
Vaticano II ter clarificado, há mais de cinquenta anos, que todos na Igreja - Povo de Deus - são incorporados a Cristo pelo batismo e têm a mesma dignidade ${ }^{5}$ e que os cristãos leigos são caracterizados pela "índole secular", constata-se que é preciso crescer nesta consciência e abandonar a ideia de que os leigos são cristãos "de segunda categoria", noção errônea alimentada por estruturas igualmente viciadas nesta maneira de auto identificação. Isto implica assumir o Batismo de maneira renovada, como consagração fundamental que realiza a inserção em Cristo e a participação em sua vida, quer seja na missão da Igreja, quer seja nas realidades temporais. Cristão leigos e leigas "levam ao mundo a esperança do Reino", ao mesmo tempo em que "trazem à Igreja as questões e interrogações do mundo" . Isto implica uma consciência de cidadania plena no seio da comunidade eclesial e uma maior sensibilidade às interpelações da fé, especialmente aquelas que brotam das situações de conflitos e tensões vividas no mundo da família, do trabalho ou da cidade, em orientação a um mundo de mais justiça e solidariedade, para todos e todas.

O Papa Francisco se associou à iniciativa da $\mathrm{CNBB}$ em inaugurar $o$ ano dedicado ao laicato e enviou uma mensagem ao presidente da Comissão Episcopal para o Laicato, mas tendo por destinatários cada cristão leigo e leiga brasileiro. ${ }^{8}$ Nessa Carta, Francisco os anima a se sentirem "interpelados pela chamada a ser protagonistas da 'nova saída missionária' que Deus pede à Igreja”. Isto significa, em primeiro lugar, uma consciência nova de não se encerrar na instituição paroquial ou diocesana mas, sim, "sair porta fora", para procurar e encontrar tanta gente que espera o Evangelho. Assim, a consagração pelo Batismo e Confirmação leva à missão particular de transformar as realidades terrenas, "para que toda atividade humana seja transformada pelo Evangelho". Em segundo lugar, Francisco lembra que esta nova saída missionária é concreta e vivida na situação atual brasileira: "é preciso que os cristãos assumam sua responsabilidade de ser o fermento de uma sociedade renovada, onde a corrupção e a desigualdade deem lugar à justiça e solidariedade".

\footnotetext{
Lumen Gentium, n. 32.

Lumen Gentium, n. 31.

KUZMA, Cesar; SANTINON, Ivenise T. G. A teologia do laicato no Concílio Vaticano II. In: Sujeitos no mundo e na Igreja. São Paulo: Paulus, 2014. p. 142.

8 Mensagem do Papa Francisco na inauguração do Ano do Laicato a D. Severino Clasen. Vaticano, 15 de novembro de 2017. Disponível em: <http://www.cnlb.org.br/?p=2531> Acesso em: 15 fev. 2018.
} 
Dois elementos teológico-pastorais chamam a atenção nesta pequena mensagem do Papa: uma nova consciência de sair dos limites da instituição paroquial ou diocesana para evangelizar, enraizada na consagração pelo Batismo e Confirmação, e a concretização da justiça e solidariedade numa realidade brasileira marcada pela corrupção e pela desigualdade.

Com este pano de fundo, passamos às dimensões da espiritualidade laical, iniciando pela dimensão pessoal.

\section{Dimensão pessoal: espiritualidade forte, integrada e encarnada}

Uma espiritualidade forte e integrada é o que se pede aos cristãos leigos e leigas. No século XVI, Santa Teresa de Jesus convocava os cristãos a uma especial fortaleza na espiritualidade: "especialmente nestes tempos em que os amigos de Deus precisam ser fortes". ${ }^{9}$ Fortaleza que se dava no aprofundamento da relação de amizade com Jesus - amizade saboreada e cultivada - e que gerava liberdade, compromisso e alegria. Ora, o convite à fortaleza na espiritualidade é um desafio de ontem e de hoje. Vejamos os elementos principais desta espiritualidade laical em dimensão pessoal.

\subsection{Um pequeno itinerário marcado pela lógica da encarnação}

Um pequeno itinerário para a vivência da espiritualidade laical foi proposto pelos bispos latino-americanos na Conferência de Puebla. A formulação permanece iluminadora e atual como ponto de partida. ${ }^{10}$

O primeiro passo consiste em não buscar o caminho de fuga das realidades temporais para encontrar a Deus, mas, ao contrário, perseverar no meio delas, de forma presente e ativa, para descobrir, ali, a presença do Senhor. Continuando o itinerário, esta perseverança ativa busca infundir, nesta realidade temporal, as inspirações da fé e uma intencionalidade ou

9 SANTA TERESA DE JESUS. Livro da Vida. 3. ed. São Paulo: Paulus, 1983. cap. 15, 5, p. 113.

10 CELAM. A evangelização do presente e no futuro da América Latina. Conclusões: Puebla. 2. ed. São Paulo: Loyola, 1979. n. 797-798, p. 252 (de ora em diante citado como Puebla, seguido do número correspondente). 
sentido de caridade cristã. Outro passo é, à luz da fé, descobrir a presença do Senhor naquela realidade. Parte essencial do itinerário, em meio aos conflitos e tensões que a missão nas realidade sociais suporta, é renovar a identidade cristã pelo contato com a Palavra de Deus, pela intimidade com o Senhor na Eucaristia e sacramentos, e pela oração.

Este itinerário espiritual proposto pela Igreja latino-americana visibiliza a realidade teologal, eclesial e teológica - não apenas sociológica - da "índole secular" que caracteriza especialmente a ação dos leigos, da qual falam o Concílio Vaticano II e, mais tarde, a Exortação Christifidelis Laici. ${ }^{11}$

Na mesma linha de inserção na realidade, os bispos brasileiros, no Ano do Laicato, convidam a uma espiritualidade "encarnada" 12 , caracterizada pela "lógica da Encarnação" fundamento o encontro com Jesus Cristo e assim valoriza os mistérios da encarnação e da redenção de Jesus Cristo. Este enfoque deve permear, afirmam os bispos, a formação laical desde o processo da iniciação cristã. Esta lógica de encarnação leva a infundir as inspirações da fé e do amor, vividos a partir do seguimento de Jesus Cristo, nos ambientes e realidades em que cristãos leigos e leigas vivem e trabalham.

A espiritualidade encarnada manifesta o encontro com Jesus Cristo, que se realiza de diferentes formas, principalmente na escuta da Palavra de Deus, na vivência dos sacramentos, na comunhão vivida na fraternidade, no estudo dos Evangelhos, no encontro com os pobres e aflitos e na oração. Este encontro multifacetado reenvia o cristão a seus ofícios ordinários na família e nos trabalhos.

\subsection{Encontro com jesus cristo, sua cruz e sua carne}

Na espiritualidade encarnada, ênfase especial é dada à oração que leva ao encontro com Deus em Jesus Cristo e assim, à vida em comunhão

11 VATICANO II. Constituição Dogmática Lumen Gentium. In: COMPÊNDIO DO VATICANO II. Constituições, decretos, declarações. 20. ed. Petrópolis: Vozes, 1989. p. 77 , n. 31 (de ora em diante citada como Lumen Gentium, seguida da numeração correspondente); JOÃO PAULO II. Exortação Apostólica Christifidelis Laici. Vocação e Missão dos Leigos. Petrópolis; Vozes, 1990. p. 34-38, n. 15 (de ora em diante citada como Christifidelis Laici, seguida da numeração correspondente).

CNBB. Documento 105, n. 184-200.

13 CNBB. Documento 105, n. 184 que cita, nesta expressão, a Carta Apostólica Novo Millenium Ineunte, n. 52. 
e fecundidade apostólica. Sobre a oração, vemos no Documento dos bispos brasileiros um parágrafo significativo:

É preciso cultivar um espaço interior dinamizado por um espirito contemplativo que ajude a cuidar da integridade da consciência e do coração e dê sentido cristão ao compromisso e às atividades. ${ }^{14}$

O "espírito contemplativo" permite reafirmar, no dia-a-dia, de forma sempre renovada, a ressoar no interior do coração como experiência e convicção pessoais, o valor da fé em Cristo, carregada de humanidade e humanização:

Toda a vida de Jesus, a sua forma de tratar os pobres, os seus gestos, a sua coerência, a sua generosidade simples e quotidiana e, finalmente, a sua total dedicação, tudo é precioso e fala à nossa vida pessoal. Todas as vezes que alguém volta a descobri-lo, convence-se de que é isso mesmo o que os outros precisam, embora não o saibam. ${ }^{15}$

Num movimento de aprofundar as melhores intuições do Documento de Aparecida, o Papa Francisco tem insistentemente convidado a uma espiritualidade ancorada no encontro com Jesus Cristo, com sua carne e sua cruz, o que significa que uma espiritualidade nunca pode ser puramente espiritual. ${ }^{16}$ Ela será sempre relacional, integradora e missionária.

Todos são convocados a descobrir e transmitir a "mística de viver juntos"17, e isto implica na ação concreta de misturar-se com as outras pessoas, oferecer o braço, apoiar-se, correr o risco de encontrar-se com o olhar e o rosto concreto do outro. Fora desta mística, a espiritualidade não será cristã, mas alienante e não responderá à sede de Deus com que a realidade interpela o cristianismo. $\mathrm{O}$ encontro com Cristo coloca os cristãos num processo de criar vínculos, enfrentar dificuldades, suportar incômodos e sofrimentos advindos do fortalecimento de uma vida comprometida. Ele cria motivos para viver e morrer.

O encontro com Jesus Cristo provoca integração entre pensamentos e sentimentos, pela força da Palavra de Deus, que trespassa a

14 CNBB. Documento 105, n. 186.

15 PAPA FRANCISCO. Exortação Apostólica Evangelii Gaudium. A alegria do Evangelho. Brasília: CNBB, 2013. n. 265, p. 151, de ora em diante citado como Evangelii Gaudium, seguido do número correspondente.

16 Cf. Evangelii Gaudium, n. 87.

17 Evangelii Gaudium, n. 87. Ver também n. 88-92. 
pessoa como um todo. A familiaridade com os Evangelhos exige, sim, um mínimo de aprofundamento teológico, mas vai além dele, em direção a uma interiorização da Palavra que gera transformações profundas no coração e na mente, integrando-os e gerando uma "nova mentalidade" 18 . Assim sendo, o encontro com Cristo pela Palavra purifica as intenções do coração, discerne os sentimentos e assim integra corpo, coração, mente e espírito.

O encontro com Jesus Cristo tem poder irradiador, ele gera discípulos missionários. Uma força centrípeta, em direção ao centro de si, está agregada à poderosa força centrífuga que faz brilhar a verdade do Evangelho através do testemunho no mundo. A espiritualidade cristã integra, necessariamente, transformação do coração e compromisso social. ${ }^{19}$ Esta é a única orientação verdadeiramente válida, pela lógica da encarnação, no interior da qual Jesus ordena que o tesouro maior do coração seja o Reino de Deus (Mt 6,21; 13,44) e, ao mesmo tempo, que esta força do coração se traduza no amor concreto (Mt 25,40). Outras propostas são mutiladoras do Evangelho, parciais e desagregadoras. Sim, é verdade que esta integração é constantemente ameaçada pela fraqueza humana, pela "busca doentia de si mesmo, pela comodidade egoísta" 20 - tentações que se apresentam à fragilidade humana. Por isso o necessário aprofundamento no "espaço interior que dê sentido cristão ao compromisso e à atividade" 21 .

A espiritualidade encarnada é assim uma espiritualidade integral. Pela força do encontro com Jesus Cristo ela implica não apenas a conversão pessoal, mas renovação da experiência comunitária, compromisso formativo, compromisso missionário na Igreja e nas realidades sociais, especialmente naquelas em que se encontra em jogo a vida dos pobres, aflitos e doentes. Comunhão e missão acontecem na experiência de alteridade, interação de diferenças e diálogo.

\subsection{Atenção a propostas de espiritualidades desagregadoras}

Neste espírito da espiritualidade forte, encarnada e integral, fica claro porque o Documento 105 alerta para as "místicas que não servem".

\footnotetext{
18 Evangelii Gaudium, n. 149. Ver também n. 150 e 151.

19 Evangelii Gaudium, n. 262.

20 Evangelii Gaudium, n. 263.

21 Evangelii Gaudium, n. 262.
} 
O espírito de "revelações privadas", devocionismos próprios de uma vivência individual e sentimental da fé e propostas místicas desprovidas de vigoroso compromisso social e missionário não se coadunam com ela. São vistos como propostas parciais e desagregadoras que mutilam o Evangelho. ${ }^{22}$

Igualmente daninho é o "mundanismo espiritual", termo cunhado pelo Papa Francisco e assumido no Documento. ${ }^{23}$ Este mundanismo é sutil precisamente porque, aparentemente, é espiritual. Apresenta uma roupagem de espiritualidade, mas confia em suas próprias forças, por isso configura-se como um neo-pelagianismo (uma versão atual da corrente da antiguidade que afirmava a capacidade do ser humano de salvar-se por suas próprias forças). Este mundanismo pode atingir a liturgia, quando exagerada e exibicionista; manifesta-se em atitudes de fidelidade às normas e seguranças doutrinais e disciplinares, com sua tendência a analisar, desqualificar e controlar os demais; camufla-se no fascínio de poder mostrar conquistas sociais e políticas; esconde-se num funcionalismo empresarial dentro das próprias comunidades. Enfim, o discernimento dos espíritos que impulsionam a missão encontra sempre o seu norte no encontro sincero com os Evangelhos.

\section{Dimensão eclesial da espiritualidade laical}

A espiritualidade cristã possui uma dimensão necessária eclesial. Mas, em que direção vai este crescimento da consciência de ser Igreja? Duas direções são apontadas, a superação do clericalismo e a construção de uma comunhão eclesial.

\subsection{Uma espiritualidade que supera o clericalismo}

O clericalismo é uma deformação da espiritualidade laical muito presente na América Latina. Tende a identificar a Igreja com o clero e a centralizar nele a estrutura, as atividades e as decisões eclesiais, tendo por consequência o enfraquecimento da consciência dos cristãos leigos em seu ser Igreja, o esgarçamento da comunhão eclesial e o comprometimento da missão libertadora da Igreja no mundo. O clericalismo tem sido recorrentemente denunciado após o Concílio Vaticano II.

22 CNBB. Documento 105, n. 195-196.

23 Evangelii Gaudium, n. 94; CNBB. Documento 105, n. 199-200. 
Reunidos em Conferência, em Medellín, 1968, os bispos já observavam a insuficiência da resposta dos cristãos leigos aos desafios de solidariedade e libertação apresentados na trama da história latino-americana. Percebiam também a pequena integração dos mesmos na Igreja, o desconhecimento de sua legítima autonomia e a falta de assessores capazes de acompanhar as novas exigências da missão dos leigos. ${ }^{24}$

Mais tarde, os bispos latino-americanos, em Puebla, 1979, nomeavam o problema a obstaculizar a promoção efetiva do laicato: "a persistência de certa mentalidade clerical em numerosos agentes pastorais, clérigos e até mesmo leigos" 25 . Este clericalismo figurava como um dos motivos que dificultavam a participação ativa e responsável dos cristãos leigos e leigas em campos como o político, o social e o cultural, particularmente nos mundos agrário e operário.

Praticamente as mesmas palavras de Puebla são repetidas, mais tarde, na Conferência de Santo Domingo (1992), que tornou-se conhecida por proclamar a prioridade pastoral de "uma Igreja na qual os fiéis cristãos leigos sejam protagonistas" ${ }^{\prime 26}$. Além da mentalidade clerical, o texto detecta que a "dedicação preferencial de muitos leigos a tarefas intra-eclesiais e uma deficiente formação privam-nos de dar respostas eficazes aos atuais desafios da sociedade" ${ }^{27}$. Mas, apesar de se dedicarem a tarefas do interior da Igreja, fazem-nas de forma pouco consciente, pois o documento também detecta que os leigos "sentem-se católicos, mas não Igreja" 28 .

Em Aparecida (2007), os bispos latino-americanos, uma vez mais, lamentam uma "compreensão limitada do caráter secular que constitui a identidade específica dos cristãos leigos, caindo numa espiritualidade individualista e, por outro lado, adotando atitudes relativistas no que diz respeito à ética e à religião" ${ }^{29}$. Para isso, veem como fundamental

24 CELAM. Medellín, 1968. In: Documentos do CELAM. Rio de Janeiro; Medellín; Puebla; Santo Domingo; São Paulo: Paulus, 2005. p. 161-163. Parte 10. Movimentos leigos, n. $1.4 ; 1.5 ; 2.2 ; 2.3$.

Puebla, n. 784. Cf. também n. 785.

CELAM. Conclusões da IV Conferência do Episcopado Latino-Americano. Santo Domingo. Texto oficial. 2. ed. São Paulo: Paulinas, 1992. p. 125, n. 103 (de ora em diante citado como Santo Domingo, seguido do número correspondente).

27 Santo Domingo, n. 96.

28 Santo Domingo, n. 96.

29 CELAM. Documento de Aparecida. Texto conclusivo da V Conferência Geral do Episcopado Latino-Americano e do Caribe. 1. ed, 2008; $15^{a}$ reimpressão. Brasília; São Paulo: CNBB/Paulus/Paulinas, 2008, n. 100c (de ora em diante citada como Aparecida, seguida do número correspondente). 
uma formação que os ajude na atuação como "discípulos missionários no mundo, na perspectiva do diálogo da transformação da sociedade" ${ }^{\text {", }}$, com incidência real nela.

Vemos, portanto, como o clericalismo se configura como uma mentalidade enraizada fortemente na Igreja latino-americana, renitente como uma erva daninha, que atinge precisamente aquilo que é específico da vocação laical, a sua "índole secular", aquela que faz com que o cristão perceba que o seu compromisso como Igreja o leva ao

mundo vasto e complicado da política, da realidade social e da economia, como também o da cultura, das ciências e das artes, da vida internacional, dos "mass media" e, ainda, outras realidades abertas para a evangelização, como sejam o amor, a família, a educação das crianças e dos adolescentes, o trabalho profissional e o sofrimento. ${ }^{31}$

É ali que os cristãos, impregnados do Evangelho, expandem o Reino de Deus, ajudam a frutificar as sementes evangélicas já presentes e operantes nas coisas do mundo e assim se colocam ao serviço da salvação em Jesus Cristo.

A mentalidade clerical atinge também o processo no qual os cristãos leigos se tornam sujeitos eclesiais. Perde-se de vista a dignidade e responsabilidade da consagração batismal reafirmada no Concílio Vaticano II, em seu movimento de volta às fontes evangélicas e patrísticas. O cristão leigo é reduzido a colaborador na Igreja, e não corresponsável de seu ser e missão. O clericalismo mantém os cristãos leigos alienados de sua consciência de ser Igreja e à margem das decisões. ${ }^{32}$

Tão forte é esta mentalidade na América Latina, que chama a atenção a contundência das palavras do Papa Francisco na Carta ao Cardeal Marc Ouellet. ${ }^{33}$ Inicia recordando a famosa frase: 'Chegou a

$30 \quad$ Aparecida, n. 283.

31 PAULO VI. Exortação Apostólica Evangelii Nuntiandi, n. 70. Disponível em: <http://w2.vatican.va/content/paul-vi/pt/apost_exhortations/documents/hf_p-vi_ exh_19751208_evangelii-nuntiandi.html>. Acesso em: 20 jan. 2018. Cf. Christifidelis Laici, n. 23.

32 CNBB. Documento 105, n. 126; Evangelii Gaudium, n. 102.

33 PAPA FRANCISCO. Carta ao Cardeal Marc Ouellet, Presidente da Pontifícia Comissão para a América Latina. Disponível em: <https://w2.vatican.va/content/francesco/ pt/letters/2016/documents/papa-francesco_20160319_pont-comm-america-latina. html>. Acesso em: 20 jan. 2018. Também: BOGAZ, Antônio S.; HANSEN, João H. Papa Francisco e a crítica ao clericalismo. In: OBSERVATÓRIO ECLESIAL BRASIL. 
hora dos leigos', mas observa: "parece que o relógio parou." Na mesma carta, chama o clericalismo de "deformação" que "anula a personalidade dos cristãos" e, ainda pior, tende a "diminuir e a subestimar a graça batismal que o Espírito Santo pôs no coração do nosso povo". O clero, ao tratar os cristãos leigos como "mandatário", limita as "iniciativas, esforços e audácias" necessárias para "anunciar a Boa Nova do Evangelho em todos os âmbitos da atividade social e, sobretudo, política". O clericalismo, "apaga pouco a pouco o fogo profético do qual a inteira Igreja está chamada a dar testemunho no coração dos seus povos". Esquece que "a visibilidade e a sacramentalidade da Igreja pertencem a todo o povo de Deus (cf. Lumen gentium, 9-14) e não só a poucos eleitos e iluminados".

O clericalismo é, portanto, um problema teologal e teológico, ao atingir a noção mesma da Igreja e da ação da graça batismal em todos os cristãos. Ele compromete a responsabilidade de todo o Povo de Deus em seu ser e missão, inibe a ação pastoral e a ação evangelizadora na sociedade, ao serviço ao Reino de Deus.

$\mathrm{Na}$ interrelação entre a presença dos cristãos leigos na Igreja e no mundo, o clericalismo desfigura a sugestiva síntese de Puebla: a de que os cristãos leigos são "homens da Igreja no coração do mundo, e homens do mundo no coração da Igreja" ${ }^{34}$.

\subsection{Uma espiritualidade que constrói comunhão}

Na comunidade há diversidade de vocações, carismas e ministérios ${ }^{35} \mathrm{~A}$ comunhão entre todos é chamada a ser respeitosa, de recíproca apreciação e reconhecimento. Ela exige cristãos leigos e leigas maduros e a desclericalização das mentalidades e estruturas, na Igreja. Apenas assim é possível pensar em verdadeira comunhão eclesial, numa caminhada como Povo de Deus que cumpre sua missão evangelizadora em unidade, na diversidade de ministérios. Ou seja, numa Igreja sinodal ${ }^{36}$.

Todos somos discípulos missionários. Papa Francisco e o laicato. São Paulo: Paulinas, 2017.

Puebla, n. 786; Aparecida, n. 209.

Cf. CNBB. Documento 62. Missão e ministérios dos cristãos leigos e leigas. São Paulo: Paulinas, 1999.

36 Em seu sentido etimológico, o termo grego "sínodo" significa "caminhar juntos". O exercício de caminhar juntos acontece, num primeiro nível, nas Igrejas particulares, através de seus organismos de comunhão (inclusive dos cristãos leigos); em seguida, 


\subsubsection{Construir a comunhão como verdadeiros sujeitos eclesiais}

Na direção oposta ao clericalismo, o Documento 105 da CNBB, Cristãos leigos e leigas na Igreja e na Sociedade, como já foi dito, convoca os cristãos leigos e leigas a serem verdadeiros sujeitos eclesiais para atuar na Igreja e no mundo.

O que é ser um sujeito eclesial? Primeiramente, e pelo lado negativo, o sujeito não é um objeto ou um destinatário passivo de determinações externas a ele. Ao contrário, ele tem consciência de sua identidade e missão na Igreja. Assim, é possível caminhar na direção da superação do clericalismo, e também do individualismo e do fechamento em comunidades. O clericalismo pode trazer uma sensação de comodidade para os cristãos leigos/leigas, por torna-lo apenas um "colaborador do padre", mas, em sua profundidade, já foi observado acima, ele fere e trai o mistério batismal que, ao contrário, realiza a inserção em Cristo e gera sujeitos livres, criativos e corresponsáveis pelo ser e missão da Igreja. O individualismo, por sua vez, é força cultural tremenda que se fecha à comunhão oferecida por Deus e à missão na sociedade. Por último, o fechamento em comunidades trai a comunhão plena e a sinodalidade, pois há dificuldade de interação com outros sujeitos eclesiais.

É o próprio Jesus a chave de um verdadeiro sujeito: “Jesus nos ensina a ser sujeitos de nossa vida" ${ }^{37}$.

Por que Jesus é verdadeiro sujeito? O Documento explicita:

Por palavras e ações, ele foi verdadeiramente sujeito de sua vida e de seu ministério. Ele é modelo para todo cristão, chamado a ser sujeito livre e responsável, capaz de opções, de decisões e de um amor incondicional. $^{38}$

no nível das Províncias Eclesiásticas e Conferências Episcopais e, em terceiro nível, na Igreja universal, com o Sínodo dos Bispos. A sinodalidade traduz a ideia da Igreja Povo de Deus, que cumpre sua missão evangelizadora em verdadeira unidade na diversidade de carismas e ministérios. O caminho sinodal que culmina no Sínodo dos Bispos é um dos frutos mais importantes do Concílio Vaticano II. Cf. ROCHA, Cardeal Sérgio da. 3. Sinodalidade: caminhar juntos na missão. In: CNBB. Missão permanente. Reflexões e propostas. $4^{\circ}$ Congresso Missionário Nacional. Brasília: CNBB, 2017. p. 55-63.

CNBB. Documento 105, n. 91.

CNBB. Documento 105, n. 91. 
Observemos acima as características esperadas de um verdadeiro sujeito: liberdade, responsabilidade, capacidade de opções e de decisões, capacidade de amar incondicionalmente.

Continuando a caracterização de Jesus como sujeito, no mesmo parágrafo, são descritas a origem e as interpelações de suas atitudes:

Suas atitudes convidam a uma nova maneira de ser, que brota do coração transformado, não da lei. Suas decisões manifestaram os caminhos concretos do amor 'até o fim' (Jo 13,1). E é através dele, "caminho, verdade e vida" (Jo 14,6) que podemos chegar a Deus.

Assim sendo, é Jesus mesmo a origem do discípulo como sujeito:

No seguimento de Jesus, como seus discípulos, todos somos sujeitos de nossa vida e de nossa missão, conscientes de nossa dignidade, livres de qualquer escravidão e capazes de doar-nos ao serviço do Reino de Deus, da comunhão eclesial e do amor ao próximo. ${ }^{39}$

Mas não se trata de um seguimento externo, como a um líder. Trata-se de algo mais substancial, que nos é dado pela fé e na fé: "A fé em Jesus Cristo nos insere em sua vida, em seus sentimentos, em sua própria pessoa e em sua missão (Jo 15,1-8; F1 2,5) [...] nos impulsiona e convoca a ser verdadeiros sujeitos na Igreja e na sociedade" ${ }^{40}$.

Isto implica uma mudança do coração e da mentalidade em direção a uma verdadeira comunhão. Cristãos leigos e leigas precisam ver-se como realmente "corresponsáveis' do ser e do agir da Igreja" lismo torna-se fundamental para comunidades de sujeitos livres e criativos, em comunhão que em nada se assemelha à subserviência, à tutela ou a comodidades na missão na sociedade e na Igreja. Nessa missão, a comunhão eclesial não pode se esquecer dos pobres, ao contrário, ela entra no movimento de privilegiá-los; ninguém pode se eximir deste mandato evangélico.

\subsubsection{Construir a comunhão na liberdade, na autonomia e na relacionalidade}

Para o desenvolvimento deste "ser sujeito" dos cristãos leigos e leigas, o Documento 105 destaca três características: a liberdade, a

\footnotetext{
39 CNBB. Documento 105, n. 91.

40 CNBB. Documento 105, n. 91.

41 CNBB. Documento 105, n. 87.
} 
autonomia e a relacionalidade com relação aos ministros ordenados. Qual dessas realidades é a mais importante? Poderíamos dizer que, nesta tríade, a mais importante é a partícula "e". Cada cristão se revela sujeito ao assumir essa liberdade, essa autonomia e essa relacionalidade, num movimento de interação e fecundação mútuas. O sujeito eclesial

é livre quando toma consciência da nova criatura que se tornou livre em Cristo e da realidade na qual está inserido; é autônomo, quando é capaz de decidir por si mesmo; é relacional, quando se abre aos outros e ao mundo. Dessa maneira, descobre-se responsável por si e pelos outros. ${ }^{42}$

Liberdade, autonomia e relacionalidade não são apenas características de cada ser humano maduro, mas são, antes de tudo, um dom do Cristo crucificado e ressuscitado. É o próprio Cristo quem oferece a todos a possibilidade de se fazerem sujeitos. Particularmente, Cristo "torna sujeitos os que não são considerados em sua dignidade pessoal, como os pobres e marginalizados", porque, com Jesus, "sua autonomia é recuperada em novas relações de amor e afeto que libertam (Lc 7,36-50; Jo 8,1-11; Mc 5,1-20; Lc 19,1-10)"'43.

Assim sendo, a comunhão, na Igreja, se dá entre batizados, libertos para a vida nova no serviço e no amor. Comunhão não se opõe à liberdade, ao contrário, ela gera liberdade para o amor concreto; a recíproca também é verdadeira, pois a liberdade do amor promove comunhão. As relações, no interior da Igreja, são chamadas a ser um espaço para a aprendizagem e a experiência de liberdade, autonomia e relacionalidade.

\subsubsection{Construir a comunhão no exercício concreto das atividades eclesiais}

A espiritualidade laical se alimenta na experiência concreta em organismos de participação e corresponsabilidade. Exemplos são os Conselhos Pastorais, tanto paroquiais quanto em níveis mais amplos, como o diocesano, regional e nacional. Já observou o Papa Francisco que "O bom funcionamento dos conselhos é determinante. Acho que estamos muito atrasados nisso" ${ }^{44}$. Outros exemplos podem ser vistos na

42 CNBB. Documento 105, n. 123.

43 CNBB. Documento 105, n. 124.

44 FRANCISCO, Encontro com a Comissão de Coordenação do CELAM, in: Mensagens e Homilias - JMJ Rio 2013. Brasília: Edições CNBB, 2013. n. 4, p. 91. Cf. CNBB. Documento 105, n. 141. 
dinâmica da religiosidade popular ${ }^{45}$, dos grupos bíblicos, ou no exercício dos ministérios leigos nas Comunidades Eclesiais de Base ${ }^{46}$.

Dentro destas experiências de comunhão, ressoa a necessidade de mudanças nas estruturas eclesiais em todos os seus níveis, com suas dinâmicas. Dentre estas estruturas, não é excluída a revisão e ampliação do Código de Direito Canônico, no sentido de remodelação de estruturas orientadas ao laicato. Este não poderia ter mais direitos de intervenção nos serviços e ministérios eclesiais? Os corpos representativos dos leigos não poderiam ter maior intervenção na tomada de decisões nas diversas instâncias eclesiais, incluindo-se as reuniões sinodais? Estas são tarefas de futuro para a Igreja. ${ }^{47}$

\section{Dimensão sociopolítica: rumo à superação da velha dicotomia entre fé e vida}

A dimensão sociopolítica da espiritualidade convoca à abertura aos areópagos que hoje desafiam a solidariedade concreta dos cristãos no mundo. ${ }^{48}$ Como enfrentar o vasto e complexo mundo das realidades temporais sem expressar, na vida concreta, as "virtudes sociais e políticas"49?

Espiritualidade e política se articulam internamente porque ambas são chamadas a acolher o mesmo dinamismo: o amor. O cristão leigo e leiga, convidado a ser verdadeiro sujeito eclesial, é chamado a abrir-se a este dinamismo.

Por um lado, a espiritualidade é um movimento integral e integrador de deixar-se conduzir pelo Espírito de Deus (Rm 8,14), que é Espírito de amor, pois Deus é amor. Por sua vez, a política é uma forma

45 Cf. FRANCISCO. Carta ao Cardeal Marc Ouellet, já mencionada neste texto.

CARIAS, Celso. O ministério leigo na comunidade eclesial. In: GRUPO DE REFLEXÃO DA COMISSÃO EPISCOPAL DE PASTORAL PARA O LAICATO DA CNBB. Sujeitos eclesiais. Sal da terra e luz do mundo. Reflexões sobre o Documento 105. São Paulo: Paulinas, 2017. p. 37-46.

47 DEMEL, Sabine. De la ayuda subordinada a la cooperación al mismo nível. La remodelacón del laicado para que la estrutura eclesial deje de estar centrada en el clero. Concilium 368 (2016) 739-750. Compilação em Selecciones de Teología. Vol. 56, n. 223 (2017), p. 227-233.

48 Cf. PEDROSA-PÁDUA, Lúcia. Espiritualidade e política: cinco apelos aos cristãos leigos e leigas. In: GRUPO DE REFLEXÃO DA COMISSÃO EPISCOPAL DE PASTORAL PARA O LAICATO DA CNBB. Sujeitos eclesiais. Sal da terra e luz do mundo. Reflexões sobre o Documento 105. São Paulo: Paulinas, 2017. p. 57-67. 
do amor, pois o amor, afirmou Bento XVI, dinamiza não apenas as microrrelações, como amigos, família ou pequenos grupos, mas também as macrorrelações, como os relacionamentos sociais, econômicos e políticos. ${ }^{50}$ A política é, nas palavras do Papa Francisco, "uma das formas mais preciosas da caridade" ${ }^{51}$.

O Documento 105 traz um apelo a cultivar uma espiritualidade que ajude a superar algumas relações de exclusão e oposição que se encontram presentes na mentalidade de muitos cristãos leigos: a oposição-exclusão entre fé e vida; a oposição-exclusão entre sagrado e profano, a oposição-exclusão entre Igreja e mundo e a oposição-exclusão entre ser cristão e ser cidadão. Segundo esta lógico de oposição-exclusão, mães e pais de família, trabalhadores e trabalhadoras, profissionais liberais ou políticos nem sempre percebem que, através de sua dedicação, trabalho e profissão, de fato, prestam um serviço a Deus e ao testemunho da Igreja, construindo as mediações concretas do amor, da justiça e da fraternidade nas famílias e na sociedade civil.

$\mathrm{Na}$ dinâmica do encontro com Jesus Cristo vivo, vale observar como a fé se expressa em todas as dimensões da vida: pessoal (Mt 6,21), familiar (Mt 19,14; Lc 15,11), comunitária (Mt 18,21), profissional (Lc 19,8), sociopolítica (Mt 6,24; 25,35), religiosa (Mt 7,21) e ecológica (Mt 6,26). Assim, não pode haver nenhum âmbito da vida humana que esteja fora da presença e ação amorosa do Deus que "se encarnou neste nosso chão marcado pelo mal e pelo sofrimento para transforma-lo e trazer uma vida nova" ${ }^{52}$. Com relação a esta superação da relação de oposição-exclusão em direção a uma relação mais integradora, o Documento também nos traz a famosa expressão de Santa Teresa de Jesus: "Entre as panelas está o Senhor" 53 , lembrando que todos os espaços humanos, menos o pecado, podem ser mediação da maravilhosa ação libertadora de Deus.

Não há oposição entre ser cristão e ser cidadão, ao contrário, há inter-relação. O mesmo movimento que constrói a Igreja constrói também

50 BENTO XVI. Carta Encíclica Caritas in veritate. Sobre o desenvolvimento humano integral na caridade e na verdade, n. 2, 2009. Disponível em: <http://w2.vatican.va/ content/benedict-xvi/pt/encyclicals/documents/hf_ben-xvi_enc_20090629_caritas-in-veritate.html>. Acesso em: 20 jan. 2018.

51 Evangelii Gaudium, n. 205.

52 CNBB. Documento 105, n. 133a.

53 CNBB. Documento 105, n. 133b. 
cidadãos que sabem se reconhecer e conviver. Há relação entre comunhão e participação na Igreja e presença ativa no mundo. ${ }^{54}$

O compromisso sociopolítico transformador nasce do amor apaixonado por Cristo ${ }^{55}$, alimenta-se da contemplação do próprio modo de agir de Deus: ele "desce" e "entra" em nosso mundo e em nossa história para assumir em tudo a nossa existência. Por isso, quando imaginamos, erroneamente, que para encontrar e servir a Deus devemos nos "elevar", no sentido de deixar as coisas das tramas de nossa história, pedimos a conversão para agir inspirados no Evangelho: que ele nos ajude a "descer" e "entrar" em tudo o que é humano, que constrói um mundo mais humano e que nos humaniza e, ali, buscar as mediações do amor, quer sejam políticas, jurídicas, culturais ou econômicas. ${ }^{56}$ Trata-se de um serviço cristão ao mundo, missão de todo o povo de Deus.

A espiritualidade laical pode fazer um eco decidido da exortação do Papa Francisco: "Apesar de se notar uma participação de muitos nos ministérios laicais, este compromisso não se reflete na penetração dos valores cristãos no mundo social, político e econômico; limita-se muitas vezes às tarefas no seio da Igreja, sem um empenhamento real pela aplicação do Evangelho na transformação da sociedade" 57 .

\section{Dimensão ecológica e universal da espiritualidade}

A dimensão ecológica não pode estar fora dos esforços da espiritualidade laical em acolher o Espírito de Deus. Toda força de interconexão e interdependência do cosmos reflete o amor e a comunhão de Deus Trindade. O ser humano, como consciência desta comunhão, pode dar voz à natureza ferida e todos os seus danos - de forma particular aos pobres da terra - e é capaz de recomeçar uma nova história, em que o individualismo e a autorreferencialidade são superados em prol de uma existência solidária com todos. ${ }^{58}$ Toda atividade humana tem uma

\footnotetext{
54 CNBB. Documento 105, n. 170. sília: CNBB, 2015. n. 208, p. 123, de ora em diante citada como Laudato si, seguida do número correspondente.
} 
dimensão ecológica e não pode ser separada dela. Todo compromisso sociopolítico está relacionado a um compromisso ecológico.

Na plena comunhão, o ser humano é colocado integralmente em suas relações fundamentais: com Deus, com os seres humanos, com a terra, consigo mesmo. A terra é nossa casa-comum, e pode ser comparada com uma mãe ou irmã "com quem partilhamos a existência" ${ }^{59}$. Grande alienação é esquecer que somos, nós mesmos, terra (cf. Gn 2,7). "O nosso corpo é constituído pelos elementos do planeta; o seu ar permite-nos respirar, e a sua água vivifica-nos e restaura-nos" ${ }^{" 60}$.

A espiritualidade laical acolhe toda a família humana, chamada a se tornar "família de Deus" ${ }^{11}$ pelo testemunho e trabalho dos cristãos, em esperançosa parceria com todos as mulheres e homens de boa vontade, $\mathrm{e}$ em diálogo com as diferentes religiões e formas de pensar a Deus. Somos membros de uma mesma humanidade. A renovação da espiritualidade parte da "consciência basilar" 62 de nossa origem comum, uma pertença recíproca e um futuro partilhado por todos. Apenas esta consciência pode fazer ver a necessidade e possibilidade de uma mudança enquanto humanidade em direção à comunhão plena.

\section{Conclusões}

A espiritualidade laical é integral e integradora. Ela se realiza na trama de múltiplas dimensões. No texto, foram ressaltadas as dimensões pessoal, comunitária, sociopolítica e ecológica. Em cada dimensão, foram sublinhados os desafios que nos pareceram mais urgentes na formação dos cristãos leigos e leigas como verdadeiros sujeitos eclesiais.

$\mathrm{Na}$ dimensão pessoal, a espiritualidade laical desenvolve a capacidade de encontrar o Senhor no interior das realidades temporais. Deixa-se inspirar e tocar pelo mistério da Encarnação, pela contemplação do Deus de Jesus Cristo, com sua vida, sua cruz e sua carne. Assim, desenvolve-se como espiritualidade forte, integradora e encarnada.

\footnotetext{
59 Laudato si, n. 1.

60 Laudato si, n. 2.

61 CONSTITUIÇÃO PASTORAL Gaudium et spes. Sobre a Igreja no mundo atual, n. 32. Disponível em: <http://www.vatican.va/archive/hist_councils/ii_vatican_council/documents/vat-ii_const_19651207_gaudium-et-spes_po.html>. Acesso em: 28 jul. 2017.

62 Laudato si, n. 202.
} 
Na dimensão eclesial, a superação do clericalismo mostra-se como desafio espiritual, urgente, a ser superado na construção de uma comunhão na diversidade de carismas e ministérios. O desenvolvimento da autonomia e liberdade na relação é aprendida na própria contemplação dos Evangelhos e é articulada com a experiência de efetiva participação e corresponsabilidade no ser e missão da Igreja, como Povo de Deus.

A dimensão sociopolítica da espiritualidade se desenvolve na superação de entraves de uma autêntica espiritualidade cristã que seja geradora de compromisso com a justiça e a solidariedade na sociedade. De forma particular, a relação de oposição e/ou exclusão entre a fé e a vida ainda se mostra forte, a interpelar uma necessária integração. Ligada a ela, encontra-se a dimensão ecológica da espiritualidade, pela qual o cristão leigo e leiga desenvolve um novo pensar, sentir e agir mais responsável com o presente e o futuro do planeta.

Enfim, no discurso sobre a espiritualidade laical, o que está em jogo é dar um passo a mais na formação de verdadeiros sujeitos eclesiais e de cristãos que se abrem às realidades que gritam por justiça e amor, para ali encontrar a Deus e contribuir para a expansão do seu Reino.

\section{Referências}

BENTO XVI. Carta Encíclica Caritas in veritate. Sobre o desenvolvimento humano integral na caridade e na verdade, 2009. Disponível em: $<$ http:/w2.vatican.va/content/benedict-xvi/pt/encyclicals/documents/ hf_ben-xvi_enc_20090629_caritas-in-veritate.html>. Acesso em: 20 jan. 2018.

BOGAZ, Antônio S.; HANSEN, João H. Papa Francisco e a crítica ao clericalismo. In: OBSERVATÓRIO ECLESIAL BRASIL. Todos somos discípulos missionários. Papa Francisco e o laicato. São Paulo: Paulinas, 2017. p. 43-57.

CARIAS, Celso. O ministério leigo na comunidade eclesial. In: GRUPO DE REFLEXÃO DA COMISSÃO EPISCOPAL DE PASTORAL PARA O LAICATO DA CNBB. Sujeitos eclesiais. Sal da terra e luz do mundo. Reflexões sobre o Documento 105. São Paulo: Paulinas, 2017. p. 37-46.

CELAM. A evangelização do presente e no futuro da América Latina. Conclusões: Puebla. 2. ed. São Paulo: Loyola, 1979. 
CELAM. Conclusões da IV Conferência do Episcopado Latino-Americano. Santo Domingo. Texto oficial. 2. ed. São Paulo: Paulinas, 1992.

CELAM. Documento de Aparecida. Texto conclusivo da V Conferência Geral do Episcopado Latino-Americano e do Caribe. 1. ed.; 15. reimpressão. Brasília: CNBB; São Paulo: Paulus; São Paulo: Paulinas, 2008.

CELAM. Medellín, 1968. In: Documentos do CELAM. Rio de Janeiro; Medellín; Puebla; Santo Domingo; São Paulo: Paulus, 2005.

CNBB. Cristãos leigos e leigas na Igreja e na Sociedade. Sal da Terra e Luz do Mundo (Mt 5,13-14). Documento 105. Brasília: CNBB, 2016.

CNBB. Documento 62. Missão e ministérios dos cristãos leigos e leigas. São Paulo: Paulinas, 1999.

DEMEL, Sabine. De la ayuda subordinada a la cooperación al mismo nível. La remodelacón del laicado para que la estrutura eclesial deje de estar centrada en el clero. Concilium 368 (2016) 739-750. Compilação em Selecciones de Teología Vol. 56, n. 223 (2017), p. 227-233.

FRANCISCO, Encontro com a Comissão de Coordenação do CELAM. In Mensagens e Homilias - JMJ Rio 2013. Brasília: Edições CNBB, 2013.

JOÃO PAULO II. Exortação Apostólica Christifidelis Laici. Vocação e Missão dos Leigos. Petrópolis: Vozes, 1990.

KUZMA, Cesar e SANTINON, Ivenise T. G. A teologia do laicato no Concílio Vaticano II. In: Sujeitos no mundo e na Igreja. São Paulo: Paulus, p. 123-143.

PAPA FRANCISCO. Carta ao Cardeal Marc Ouellet, Presidente da Pontifícia Comissão para a América Latina. Disponível em: <https:// w2.vatican.va/content/francesco/pt/letters/2016/documents/papa-francesco_20160319_pont-comm-america-latina.html>. Acesso em: 20 jan. 2018.

PAPA FRANCISCO. Encíclica Laudato si. Sobre o cuidado da casa comum. Brasília: CNBB, 2015.

PAPA FRANCISCO. Mensagem do Papa Francisco na inauguração do Ano do Laicato a D. Severino Clasen. Vaticano, 15 de novembro de 2017. Disponível em: $<$ http://www.cnlb.org.br/?p=2531 $>$. Acesso em: 15 fev. 2018. 
PAPA FRANCISCO. Exortação Apostólica Evangelii Gaudium. Brasília: CNBB, 2013.

PASSOS, João Décio. A emergência do sujeito na Igreja. In: Sujeitos no mundo e na Igreja. São Paulo: Paulus, 2014. p. 25-43.

PAULO VI. Exortação Apostólica Evangelii Nuntiandi. Disponível em: $<$ http://w2.vatican.va/content/paul-vi/pt/apost_exhortations/documents/ hf_p-vi_exh_19751208_evangelii-nuntiandi.html >. Acesso em: 20 jan. 2018 .

PEDROSA-PÁDUA, Lúcia. Espiritualidade e política: cinco apelos aos cristãos leigos e leigas. In: GRUPO DE REFLEXÃO DA COMISSÃO EPISCOPAL DE PASTORAL PARA O LAICATO DA CNBB. Sujeitos eclesiais. Sal da terra e luz do mundo. Reflexões sobre o Documento 105. São Paulo: Paulinas, 2017. p. 57-67.

ROCHA, Cardeal Sérgio da. 3. Sinodalidade: caminhar juntos na missão. In: CNBB. Missão permanente. Reflexões e propostas. $4^{\circ}$ Congresso Missionário Nacional. Brasília: CNBB, 2017. p. 55-63.

SANTA TERESA DE JESUS. Livro da Vida. 3. ed. São Paulo: Paulus, 1983.

VATICANO II. Constituição Dogmática Lumen Gentium. In: COMPÊNDIO DO VATICANO II. Constituições, decretos, declarações. 20. ed. Petrópolis: Vozes, 1989.

VATICANO II. Constituição Pastoral Gaudium et spes. Sobre a Igreja no mundo atual. Disponível em: $<$ http://www.vatican.va/archive/hist_councils/ii_vatican_council/documents/vat-ii_const_19651207_gaudium-et-spes_po.html>. Acesso em 28 jul. 2017. 